\title{
Dynamical systems applied to dynamic variables of patients from the intensive care unit (ICU): Physical and mathematical mortality predictions on ICU
}

\author{
Javier Rodríguez Velásquez
}

MD. Grupo Insight Head. Coordinator of Protocol C025-2014 of the Hospital Militar Central. Researcher of Clínica del Country Research Center. Teacher of Research Area, Special Internship and Seedbeds in Physical and Mathematical Theories Applied to Medicine. Faculty of Medicine - Universidad Militar Nueva Granada, Bogotá, Colombia

E-mail: grupoinsight2025@yahoo.es

\begin{abstract}
Methodologies have been developed to evaluate the heart rate (HR) chaotic dynamics, differentiating normality of chronic and acute disease and the evolution between these states; other dynamic variables of system on ICU have shown a chaotic behavior. An induction from 8 patients was realized, five discharged alive from ICU and 3 cases of mortality, defining sets and subsets, as well as operations between them that differentiate and predict the dynamics of patients who survive of those with fatal outcome, through the maximum and minimum values of chaotic attractors of 4 dynamic variables: Heart rate (HR), arterial carbon dioxide partial pressure (PACO2), venous carbon dioxide partial pressure (PvCO2), and oxygen venous saturation (SVO2). Finally a blind study was done with 12 patients, calculating sensitivity, specificity, PPV, NPV and accuracy. Also a temporal decrease in the cardiac dynamics evaluation was done, from 21 to 15 hours, through an induction with two cases, one with normal dynamic and one with acute dynamic. The occupation spaces of cardiac chaotic attractors were measured, and then a blind study was realized with 18 patients, calculating sensitivity, specificity and Kappa coefficient. The equation $T=[(B 2 \cap$ C2) U A1 U D3] U [(A2ก B1) U C3 U D1] differentiates and predicts the dynamics of patients who survive of those with fatal outcome in the ICU. The sensitivity, specificity, PPV and NPV were $100 \%$, and accuracy was 1 . Acute cardiac dynamic was differentiated of normal dynamic on 15 hours, allowing to reduce the time of the evaluation of this dynamic of 21 to 15 hours, the sensitivity and specificity values were $100 \%$ and Kappa coefficient was 1. Dynamical systems in the context of set algebra allow differentiate patients who are discharged alive from those with an adverse outcome. The evolution to death can be predicted in a physical and mathematical way in the ICU.
\end{abstract}

Keywords: Cardiac dynamic, chaotic attractor, geometry, fractal, mortality prediction, Intensive Care Unit.

\section{INTRODUCTION}

The theory of dynamical systems studies how systems evolve over time by analyzing its dynamic variables, which are represented in the phase space with geometric attractors. Such attractors can be punctual or cyclic if they describe predictable dynamics, or can be chaotic if they describe unpredictable dynamics (Devaney, 1992). The latter attractors, by its own irregularity may be characterized from fractal geometry. Founded by Mandelbrot, fractal geometry studies the irregular objects; fractals like chaotic attractors are called wild fractals, which have overlapping parts (Peitgen, 1992). Also there are abstract and statistical fractals, whose complexity is calculated with Zipf's / Mandelbrot law (Zipf, 1949; Mandelbrot, 1972; Rodríguez, 2005). The measure for characterization of fractals is the fractal dimension; there are various kinds of dimension definitions, such as Rényi dimension spectrum, correlation dimension, information dimension, between others (Kinsner, 2007; Eckmann and Ruelle 1985; Grassberger and Procaccia, 1983).

This new geometric approach has allowed to show morphological and physiological aspects of living systems (West, 1990; Goldberger and West, 1987) taking into account the irregular structure of nature (Mandelbrot, 1972). Since this new approach have been characterized 
neoplastic and normal mammographic images (Pohlman, et al., 1992; Lefebvre and Benali, 1995), lung, intestinal and neural structures, among others (Gough, 1992; Goldberger et al., 1990). Some research has achieved to geometrically distinguish normal arterial structures from pathological ones (Rodríguez et al., 2002, Rodríguez et al., 2010b) and differentiate cell types of the squamous epithelium of the cervix from normality to carcinoma (Prieto et al., 2014, Rodríguez et al., 2015b). Also the physical and mathematic theories has been applied to the analysis of cardiac dynamics from Holter and continuous ECG recordings, two test traditionally used to assess the variability of RR interval, as well as bradyarrhythmias and tachyarrhythmias, including other measures. The analysis of the variability of the heart rate from the RR changes over time was one of the greatest areas of interest in cardiology. With the application of mathematical and physical theories to the Holter record (Goldberger et al., 2002, Higgins 2002, Costa et al., 2002), it has shown that normal cardiac dynamics presents a chaotic or irregular behavior (Wu et al., 2009, Braun et al., 1998), totally contrary to the homeostatic conception, from which the diagnostic parameter of normality is regularity while irregularity was associated to disease. From this, predictive fractal dimensions of mortality following acute myocardial infarction (AMI) were developed (Huikuri et al., 2000), finding better predictors.

Evaluating the space occupation of cardiac chaotic attractors (Rodríguez et al., 2008), acute pathological dynamics were differentiated of the chronic and normal ones, confirmed with 150 cases (Rodríguez et al., 2011b) and 170 (Rodríguez et al., 2015e). Later it was applied to ICU, reducing the evaluation time of cardiac dynamics from 24 to 16 hours, achieving to establish objective and reproducible mathematical measurements that distinguish normal dynamics from those with acute illness, allowing evaluate the evolution between these states in less time (Rodríguez et al., 2015d). Also a cardiac chaotic law (Rodríguez 2011) was developed, which was applied to 115 patients (Rodríguez et al., 2013a), and finally with the probability theory and the principle of entropy was possible to differentiate normality from the chronic and acute disease, and states between them (Rodríguez, 2010b; Rodriguez, 2012a; Rodríguez et al., 2013e; Rodríguez, 2014b; Rodríguez, 2015). In the same way, the complexity degree of the normal and acute cardiac dynamics from Zipf-Mandelbrot law was found (Rodríguez et al., 2015c).

Arterial blood gases test is an invasive method to measure the $\mathrm{pH}$ and the partial pressures of oxygen (PAO2) and carbon dioxide (PACO2). Latters represent the pressure of each gas in plasma. Normal values for these arterial gases have been established for example, PAO2 normal value should be higher than $80 \mathrm{mmHg}-$ decreasing progressively with age - while the PaCO2, usually between 35 and $45 \mathrm{mmHg}$, does not change with age. On the other hand, venous blood gas test is used not just to evaluate parameters such as venous saturation - central or mixed -, venous oxygen pressure (PVO2) and carbon dioxide pressure (PVCO2); it also determines if body tissues are extracting and using the oxygen from the arterial blood and indicates if ventilation mechanisms work properly. In ICU, these measures are usually evaluated directly into the heart through a central catheter (Figueredo and González, 2010; Jiménez and Montero, 2006).

There are not systematic and unified methods for the specialized physician decisions (Gómez et al., 2000) independently of populations and patients with specific diseases. a lot of information should be taken into account simultaneously, on which the physician must decide if a specific data requires a more accurate monitoring or can be dismissed as inconsequential (Gómez et al., 2000).

From the algebra of sets, a methodology of clinical application was developed to predict from the information $\mathrm{CBC}$, the population of CD4 cells in specific ranges of leukocytes (Rodríguez et al., 2012, Rodríguez et al., 2011a; Rodríguez et al., 2013b; Rodríguez et al., 2013d; Rodríguez et al., 2014a). This methodology has been applied to 500 (Rodríguez et al., 2013b), 800 (Rodríguez et al., 2013d) cases and also it was improved and applied to 150 cases (Rodríguez et al., 2014a), in all studies the prediction percentages were up to $100 \%$. This methodology is useful for patients with HIV, because it has lower costs than the flow cytometry, which is currently considered as gold standard, but for its costs is hardly accessible for the patients of low resources.

The present study aims to predict the evolution of dynamic system variables of ICU patients, through the simultaneous application of the dynamical systems theory and set theory, developing physical and mathematical mortality predictions of clinical application. This paper also seeks to reduce the time of assessment of cardiac dynamics of 21 to 15 hours.

\section{METHODOLOGY}

\section{Definitions}

\section{Fractal}

As substantive, irregular object; as adjective, irregularity.

\section{Phases space}

Space of two or more dimensions, which is possible to plot the geometric attractor that represents the dynamics of a system, in this case the return map will be used.

\section{Return map}

Plot of a dynamical variable, in which the values are 
plotted, one against the following in sequential order.

\section{Population}

The following variable records were analized: Heart rate $(\mathrm{HR})$, arterial carbon dioxide partial pressure (PACO2), venous carbon dioxide partial pressure (PVCO2) and venous oxygen partial pressure (SVO2); this information was recorded from 20 patients; 12 came out alive (group A) and 8 with death condition (group B) from databases of postoperative intensive care unit (ICU) of the Hospital Militar Central (HMC), with ages over 21 years.

And for the study to reduce the time required for the assessment of cardiac dynamics of 21 to 15 hours, were taken 20 continuous electrocardiographic recordings or holters of patients over 21 years old; 5 normal dynamics came from Holter database of Insight Group and 15 dynamics of continuous electrocardiographic recordings corresponding to ICU patients came from records databases of postoperative ICU of HMC.

\section{Procedure}

An induction with eight patients (table 1) was developed: five discharged alive, from group $A$, and three discharged dead, from group B. Holter monitor test or continuous electrocardiographic recording were taken for each patient; maximum and minimum values for heart rate and total number of heart beats in each hour were taken. Also were measured daily values of others physiological variables during time lapses between 2 and 12 days: arterial carbon dioxide partial pressure (PACO2), venous carbon dioxide partial pressure (PVCO2), and oxygen venous saturation (SVO2), even 48 and 24 hours values before dying for mortal outcome cases.

Heart rate information was imported to software previously developed, which generates a simulation of cardiac dynamics beat to beat inside the indicated range for each time register. With this data, ordered pairs from a heart rate against the next one in time were plotted, generating a return map in the phases space in order to build the chaotic attractor of cardiac dynamics. In the same way, with maximum and minimum values from the measures of the other variables - PACO2, PVCO2, SVO2 -, assessed from central catheter, chaotic attractors were generated for each variable. Sets of each of the variables for group A and group B were defined; also subsets were defined between the sets defined for mortality and alive outcome, as well as operations between the sets and subsets searching to establish quantitative and qualitative differences between the two groups of patients analyzed in the induction.

Subsequent, a blind study was developed with data from the other 12 patients. For that purpose, diagnostic conclusions and outcome condition (dead or alive) were hidden. The mathematical evaluation developed was applied to each patient; through operations between sets and subsets, mathematics measures of alive or dead outcome were obtained. Furthermore, data was unhidden and sensitivity [SENS $=T P /(T P+F N)$ ], specificity $[S P E C=T N /(T N+F P)]$, positive predictive value (PPV) $[P P V=T P /(T P+F P)]$, negative predictive value (NPV) $\mathrm{NPV}=\mathrm{TN} /(\mathrm{TN}+\mathrm{FN})]$ and accuracy $[\mathrm{EXC}=(\mathrm{TP}+\mathrm{TN}) /$ $(T P+F P+T N+F N)]$ were found. A binary classification was used for this purpose: true positives (TP) where the number of patients whose outcome was dead and that are inside the mathematical values corresponding to dead outcome; false positives (FP) is the number of patients that mathematically behave as discharged dead and in medical history are reported as discharged alive; false negatives (FN) is the number of patients that clinically were discharged dead but whose mathematical values match with discharged alive, and finally, true negatives (TN) were defined as those patients that clinically were discharged alive and whose mathematical values match with discharged alive.

A reduction of the time needed in order to evaluate cardiac dynamic to 15 hours was also developed, in which an induction was done with a continuous electrocardiographic record with acute dynamic and a normal Holter recording. Values of maximal and minimal cardiac frequencies and the total heartbeat in 21 hours as minimum were taken, and later during 15 hour. Cardiac attractors were built for each patient and occupation spaces were measured from two grids of $5(\mathrm{Kp})$ and 10 beats/min $(\mathrm{Kg})$ and the Box counting fractal dimension was calculated such as in others works (26-28). Subsequently, obtained mathematical measurements from attractors obtained during 21 and 15 hours were compared. Finally, a blind study was developed with 14 continuous electrocardiographic recording and 4 Holters, to whom their diagnostic conclusions were masked and the mathematical evaluation to each recording was found.

To develop this blind study, the conventional diagnostic was the gold standard and this result was compared with the mathematical methodology, calculating specificity, sensitivity and Kappa coefficient. Such measures shall be made through a binary classification where the true positives (TP) are the number of patients diagnosed within the limits of abnormality and has the same mathematical diagnosis, false positive (FP) is the number of heart records that mathematically behave as studies within the abnormality and whose clinical diagnosis is normal, false negatives (FN) is the number of heart records clinically diagnosed as abnormal but whose mathematical values correspond to normal patients and finally true negative (TN) is defined as the number of heart records clinically diagnosed as normal and whose mathematical values also correspond to normal.

With the objective to evaluate the correlation between the physical-mathematical methodology and conventional 
Table 1. Clinical data of the prototypes of groups $A$ and $B$, chosen for induction. Sex: Female (F), Male (M).

\begin{tabular}{|c|c|c|c|}
\hline No. & Age & Sex & Indications \\
\hline P1 & 86 & M & Sepsis soft tissue. Chronic pulmonary disease exacerbation unspecified \\
\hline P2 & 78 & M & $\begin{array}{l}\text { Cervical disc disorder with myelopathy. UCl- Evolution Orthopedics } \\
\text { Ventilator associated pneumonia and ARDS resolved } \\
\text { Acute neuropathic pain and cervical somatic } \\
\text { POP C3C5 cervical fusion, type } 2 \text { diabetes, obesity, hypertension } \\
\text { IRC escalation in medullary shock resolution }\end{array}$ \\
\hline P3 & 70 & M & $\begin{array}{l}\text { Extahapatica malignant tumor of the biliary tract. Severe sepsis source to establish severe ARDS } \\
\text { 3A stadium cholangiocarcinoma Bismuth } \\
\text { Heavy Ex-smoking } \\
\text { POP ultrasound guided biospy of the intrahepatic biliary } \\
\text { Gram negative shock ECOLI type resolved }\end{array}$ \\
\hline P4 & 79 & $\mathrm{M}$ & COPD \\
\hline P5 & 75 & M & $\begin{array}{l}\text { Pleuropulmonar sepsis. Acute respiratory failure hypoxemia } \\
\text { Pulmonary edema } \\
\text { Decompensated congestive heart failure }\end{array}$ \\
\hline P6 & 82 & M & $\begin{array}{l}\text { Upper abdominal pain located } \\
\text { Constipation } \\
\text { Chronic obstructive pulmonary disease unspecified } \\
\text { Femoral neck fracture }\end{array}$ \\
\hline P7 & 68 & $\mathrm{~F}$ & Bleeding subracroidea \\
\hline P8 & 86 & M & $\begin{array}{l}\text { State post resuscitation coupled mechanical ventilation, nasogastric tube fusional no murmurs } \\
\text { rhythmic heart sounds, noises bilateral basal hypoventilation, tips edema not adequate distal } \\
\text { perfusion. }\end{array}$ \\
\hline
\end{tabular}

clinical diagnosis is calculated Kappa coefficient by the following formula:

$$
K=\frac{C o-C a}{T o-C a}
$$

Co: Observed concordance, that means the number of patients that represent the same diagnosis with both methodologies: physical-mathematical methodology and gold standard.

To: totality of observations, in this case, all continuous electrocardiographic recordings and Holters studied $\mathrm{Ca}$ : Random concordance that is calculated by the following formula:

$$
C a=\left[\left(f_{1} \times C_{1}\right) / T o\right]+\left[\left(f_{2} \times C_{2}\right) / T o\right]
$$

$\mathrm{F} 1$ is the number of patients who present mathematical values within normal limits, $\mathrm{C} 1$ is the number of patients clinical diagnosed within normality, F2 is the number of patients who represent mathematical values associated to illness, C2 is the number of patients clinically diagnosed with illness and $T_{0}$ is the total number of cases.

\section{Ethical considerations}

This study included the approval of the ethics committee of the Hospital Militar Central by file number 19696. This study complies with the ethical principles of the Declaration of Helsinki of the World Medical Association, and adheres to scientific, technic and administrative health research standards for the Ministry of Health of Colombia. According to the resolution 8430 of 1993, this research study is classified as safe, as calculations on results previously prescribed tests are done without any direct intervention on patients.

\section{RESULTS}

The maximum and minimum values of the attractors (see examples of the attractors for the four variables below, figures 1-4) of analyzed variables, for the patients of group A were between 51 and 226 beat/min for HR, for SVO2 between 59,7 and 93,7\%, for PVCO2 between 29,4 and $65 \mathrm{mmHg}$, and for PACO2 oscillate between 25,8 and $73,7 \mathrm{mmHg}$. For the group $B$ patients, the values were between 68 and 183 beat $/ \mathrm{min}$ for the $H R$, between 14,4 and $64,1 \mathrm{mmHg}$ for PACO2, between 

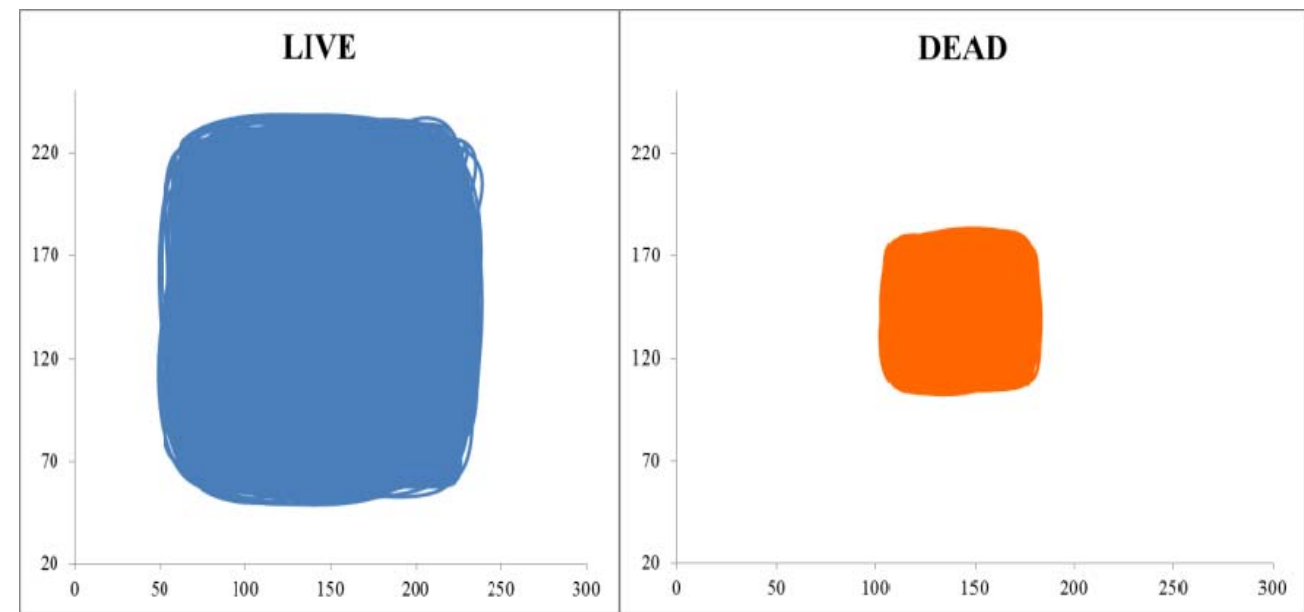

Figure 1. Attractor of HR for the prototypes P2 (dead) and P6 (alive).

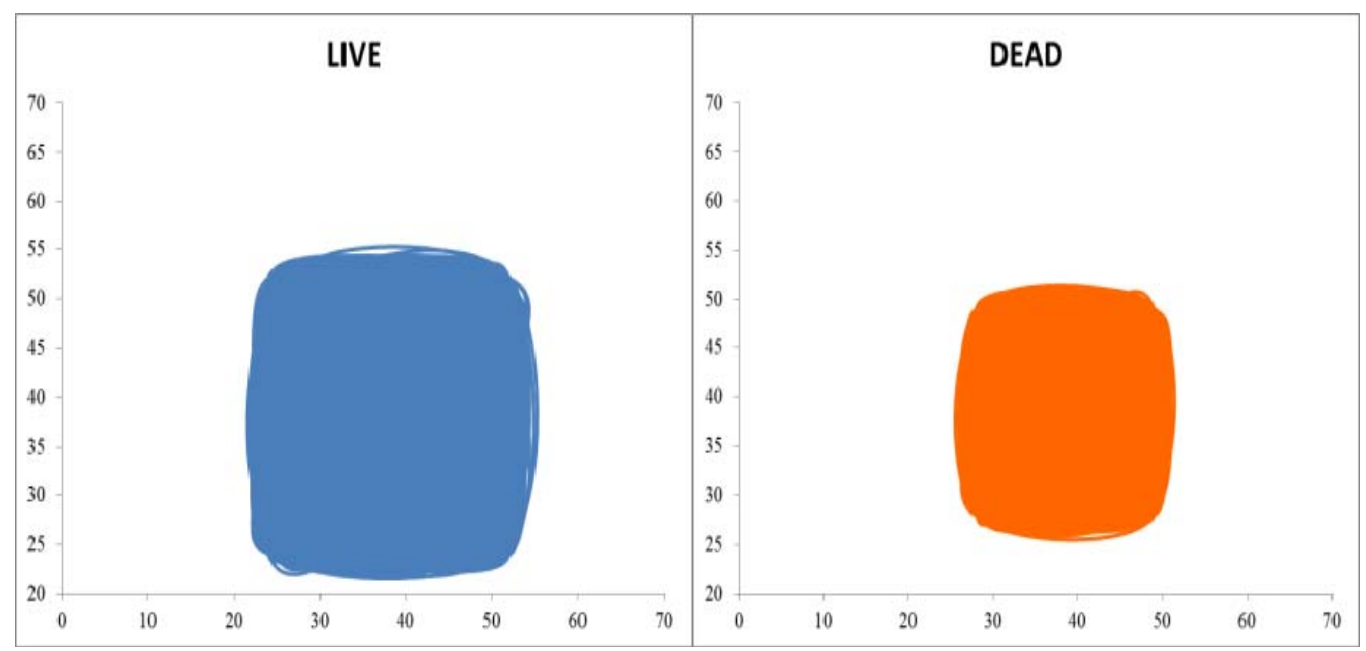

Figure 2. Attractor of PACO2 for the prototypes P2 (dead) and P6 (alive).

13 and $97,9 \mathrm{mmHg}$ for PVCO2 y for the SVO2 between 22,1 and $92 \%$.

In order to differentiate the two groups, from these maximum and minimum values, four sets, one for each variable were defined for each group, and then 12 subsets were defined, including so to all possible dynamics of variables.

For all sets and subsets, the HR units are beat/min, SVO2 is expressed in \%, and the units for PACO2 and $\mathrm{PVCO} 2$ are $\mathrm{mmHg}$.

The sets defined for the group $A$ are:

$A_{A}:\{x \in$ HR: $51 \leq x \leq 226\}$

$\mathrm{B}_{\mathrm{A}}:\{x \in \mathrm{PACO} 2: 25,8 \leq x \leq 73,7\}$

$\mathrm{C}_{\mathrm{A}}:\{x \in \mathrm{PVCO} 2: 29,4 \leq x \leq 65\}$

$D_{A}:\{x \in$ SVO2: $59,7 \leq x \leq 93,7\}$

And for the group $B$ are:

$A_{B}:\{x \in \mathrm{HR}: 68 \leq x \leq 183\}$
$\mathrm{B}_{\mathrm{B}}:\{x \in \mathrm{PACO} 2: 14,4 \leq x \leq 64,1\}$

$\mathrm{C}_{\mathrm{B}}:\{x \in \mathrm{PVCO} 2: 13 \leq x \leq 97,9\}$

$D_{B}:\{x \in$ SVO2: $22,1 \leq x \leq 92\}$

The subsets defined are:

$\mathrm{A}_{1}:\{x \in \mathrm{HR}: 51 \leq x<68\}$,

$\mathrm{A}_{2}:\{x \in \mathrm{HR}: 68 \leq x<183\}$,

$A_{3}:\{x \in \mathrm{HR}: 183 \leq x \leq 226\}$,

$\mathrm{B}_{1}:\{x \in$ PACO2: $14,4 \leq x<25,8\}$,

$\mathrm{B}_{2}:\{x \in$ PACO2: $25,8 \leq x<64,1\}$,

$\mathrm{B}_{3}:\{x \in \mathrm{PACO} 2: 64,1 \leq x \leq 73,7\}$,

$\mathrm{C}_{1}:\{x \in \mathrm{PVCO} 2: 13 \leq x<29,4\}$,

$\mathrm{C}_{2}:\{x \in \mathrm{PVCO} 2: 29,4 \leq x<65\}$,

$\mathrm{C}_{3}:\{x \in \mathrm{PVCO} 2: 65 \leq x \leq 97,9\}$,

$D_{1}:\{x \in$ SVO2: $22,1 \leq x<58,3\}$,

$D_{2}:\{x \in$ SVO2: $58,3 \leq x<92\}$,

$D_{3}:\{x \in$ SVO2: $92 \leq x \leq 93,7\}$ 


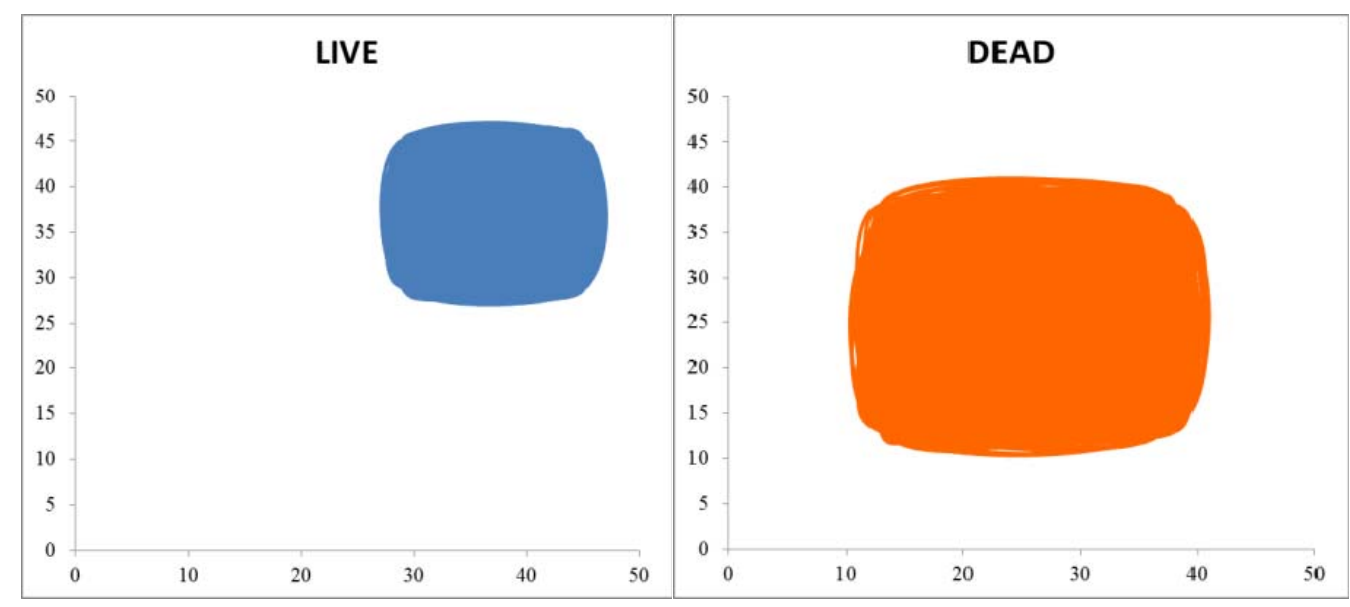

Figure 3. Attractor of PVCO2 for the prototypes P2 (dead) and P6 (alive). In in this case, contrary to the behavior of other variables, the attractor dynamics with fatal outcome, is larger than that with alive outcome

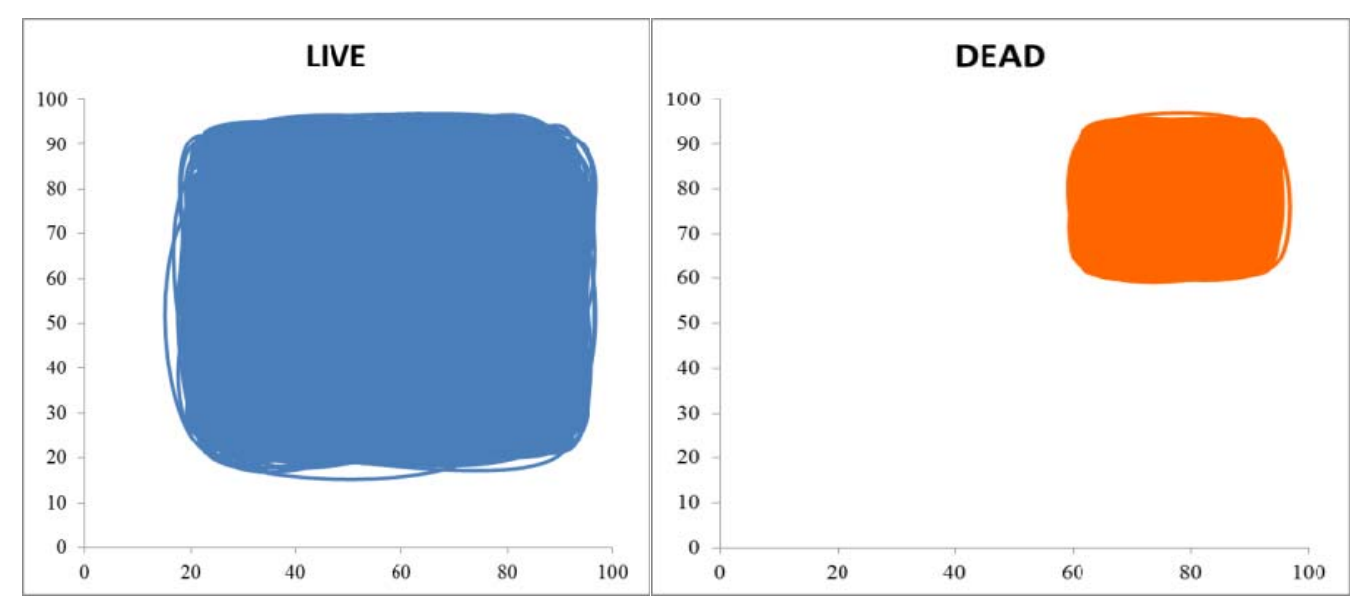

Figure 4. Attractor of SVO2 for the prototypes P2 (dead) and P6 (alive).

When analyzing the belonging of each patient to these sets using the sets algebra (table 2), the totality $(T)$ of dynamics of the variables is given by the equation, $L$ : ALIVE. D: DEAD:

$$
T=L+D=\left[\left(B_{2} \cap C_{2}\right) \cup A_{1} \cup D_{3}\right] \cup\left[\left(A_{2} \cap B_{1}\right) \cup C_{3} \cup D_{1}\right]
$$

Disjuncts sets that determine the mortality $(M)$ and alive outcome $(\mathrm{L})$ were obtained:

$L\left(A_{1}, B_{2}, C_{2}, D_{3}\right)=\left(B_{2} \cap C_{2}\right) \cup A_{1} \cup D_{3}$

$M\left(A_{2}, B_{1}, C_{3}, D_{1}\right)=\left(A_{2} \cap B_{1}\right) \cup C_{3} \cup D_{1}$

In conducting the blind study, it was established that the sensitivity, specificity, PPV and NPV were $100 \%$, and accuracy was 1 .Regarding the study for reducing the time required for analyzing cardiac dynamics from 21 to 15 hours (Table 3 ), the spaces occupied by normal attractors evaluated in 21 hours were between 75 and
111 for the grid $\mathrm{Kg}$, and between 275 and 419 for $\mathrm{Kp}$, the fractal dimensions (FD) varied between 1,5850 and 1,9296. For the pathological dynamics, FD ranged from 1,5555 and 1,$9281 ; \mathrm{Kp}$ values were between 54 and 1456 and $\mathrm{kg}$ values were between 16 and 390 .

For evaluation in 15 hours, it was found that the occupancy values for $\mathrm{Kp}$ grid of attractors of normal dynamics were between 276 and 417; for the grid $\mathrm{Kg}$ were between 76 and 111 and DF ranged from 1,5899 to 1,9095. For pathological dynamics, the DF were between 1,1699 and1,9475, Kp values were between 36 and 1439, and $\mathrm{Kg}$ took values between 16 and 399.

Comparing the space occupation of the measurements for 21 hours and 15 hours for continuous ECG records or Holter (figure 5), it was found that occupying spaces values were higher than those found in previous papers (Rodríguez et al., 2008, Rodríguez et al., $2011 b$ ), so that a new mathematical diagnosis evaluation 
Table 2.Analysis of belonging or not to the joint defined by the algebra of sets.Outcome: D:Dead, L: Alive. P: Prototype used for induction.NR: Not recorded.

\begin{tabular}{|c|c|c|c|c|c|c|c|c|c|}
\hline Outcome & No. & Age & $\operatorname{Sex}$ & $\mathrm{B}_{2} \cap \mathrm{C}_{2}$ & $\left(B_{2} \cap C_{2}\right) U A_{1}$ & $\left(B_{2} \cap C_{2}\right) \cup A_{1} U D_{3}$ & $\mathbf{A}_{2} \cap \mathbf{B}_{1}$ & $\left(A_{2} \cap B_{1}\right) U C_{3}$ & $\left(A_{2} \cap B_{1}\right) U C_{3} U D_{1}$ \\
\hline \multirow{8}{*}{$\mathrm{D}$} & P1 & 86 & $\mathrm{M}$ & & & & $\mathbf{X}$ & $\mathbf{X}$ & $\begin{array}{l}\mathbf{X} \\
\end{array}$ \\
\hline & 1 & 83 & M & & & & $\mathbf{X}$ & $\mathbf{X}$ & $\mathbf{X}$ \\
\hline & $\mathbf{P 2}$ & 78 & M & & & & & & $\mathbf{X}$ \\
\hline & $\mathbf{P 3}$ & 70 & M & & & & & $\mathbf{X}$ & $\mathbf{X}$ \\
\hline & 2 & 89 & M & & & & $\mathbf{X}$ & $\mathbf{X}$ & $\mathbf{X}$ \\
\hline & 3 & 81 & M & & & & & & $\mathbf{X}$ \\
\hline & 4 & 60 & $\mathrm{~F}$ & & & & & & $\mathbf{X}$ \\
\hline & 5 & 71 & M & & & & & & $\mathbf{X}$ \\
\hline \multirow{12}{*}{$\mathrm{L}$} & P4 & 79 & $M$ & $\mathbf{X}$ & $\mathbf{X}$ & $\mathbf{X}$ & & & \\
\hline & P5 & 75 & M & $\mathbf{X}$ & $\mathbf{X}$ & $\mathbf{X}$ & & & \\
\hline & P6 & 82 & M & $\mathbf{X}$ & $\mathbf{X}$ & $\mathbf{X}$ & & & \\
\hline & P7 & 68 & $\mathrm{~F}$ & $\mathbf{X}$ & $\mathbf{X}$ & $\mathbf{X}$ & & & \\
\hline & P8 & 86 & M & $\mathbf{X}$ & $\mathbf{X}$ & $\mathbf{X}$ & & & \\
\hline & 6 & 70 & $\mathrm{~F}$ & $\mathbf{X}$ & $\mathbf{X}$ & $\mathbf{X}$ & & & \\
\hline & 7 & 79 & $\mathrm{~F}$ & & & $\mathbf{X}$ & & & \\
\hline & 8 & 47 & M & & $\mathbf{X}$ & & & & \\
\hline & 9 & 49 & $\mathrm{~F}$ & & $\mathbf{X}$ & & & & \\
\hline & 10 & NR & $\mathrm{F}$ & & $\mathbf{X}$ & & & & \\
\hline & 11 & 68 & M & & & $X$ & & & \\
\hline & 12 & NR & $F$ & & $\mathbf{X}$ & & & & \\
\hline
\end{tabular}

was defined, establishing an acute dynamic was characterized by values less than 74 , values between 74 and 200 , and values greater than 535 are characteristic of disease, while values between 200 and 535 correspond to normal.

Subsequent to perform the blind study, sensitivity and specificity of $100 \%$ and Kappa coefficient of 1 were obtained.

\section{DISCUSSION}

This is the first work in which a predictive methodology of clinical application for the evaluation of 4 physiological variables usually used in the ICU were developed, after an induction with eight cases, five with alive outcome and three with dead outcome. This method achieved to establish differences between alive and fatal outcome in an objective, quantitative and reproducible way since dynamical systems and algebra of sets. Its predictive ability was confirmed by a blinded study, whose sensitivity, specificity, PPV and NPV were $100 \%$, and accuracy was 1 . This methodology, being based on physical and mathematical theories, allowed a simplification for the predictions of the observed phenomenon. It also was developed the reduction of the time required for assessing cardiac dynamics of 21 to 15 hours, founding a sensitivity and specificity of $100 \%$ and a Kappa coefficient of 1 . Timeless set of temporary variables of the dynamic system allow to predict irrespective of length of stay in the ICU, whether 24 hours, days, or months the limits of the values found could change, however, this does not change the essence of the mathematical methodology developed.

There are many scoring system and models for intensive care units (Knaus et al., 1985, Hosseini and Ramazani, 2015; Hsieh et al., 2014; Cismondi et al. 2015, Le Gall et al., 1993). Some of the most frequently used are APACHE-II (acute physiology andchronic health evaluation II) (Knaus et al., 1985) and SAPS II (simplified acute physiological score II) (Le Gall et al., 1993), which provide a gross estimate of mortality risks in ICU. However these scoring systems depend of measures taken in a specifical moment and the development of the patient dynamic is not taken into account, and also these scoring have shown dependence of the population (Rowan et al., 1993). The predictions developed in this paper allow making dynamic assessments over time, 
Table 3.Occupation values of cardiac chaotic attractors for 21 to 15 hours.Sex: Female (F), Male (M).FD:Fractal Dimension.

\begin{tabular}{|c|c|c|c|c|c|c|c|c|c|}
\hline & & & & \multicolumn{3}{|c|}{21 hours } & \multicolumn{3}{|c|}{15 hours } \\
\hline No & Age & Sex & Indications & $\mathrm{Kg}$ & $\mathrm{Kp}$ & FD & $\mathrm{Kg}$ & $\mathrm{Kp}$ & FD \\
\hline 1 & 43 & $\mathbf{F}$ & Study within normal limits & 99 & 297 & 1,58496 & 98 & 295 & 1,58986 \\
\hline 2 & 39 & $\mathbf{M}$ & Study within normal limits & 87 & 308 & 1,82384 & 87 & 304 & 1,80498 \\
\hline 3 & 31 & $\mathbf{F}$ & Study within normal limits & 111 & 419 & 1,91639 & 111 & 417 & 1,90949 \\
\hline 4 & 45 & $\mathbf{F}$ & Study within normal limits & 105 & 400 & 1,92961 & 106 & 397 & 1,90507 \\
\hline 5 & 31 & $\bar{M}$ & Study within normal limits & 75 & 275 & 1,87447 & 76 & 276 & 1,86060 \\
\hline 6 & 77 & M & $\begin{array}{l}\text { Abdominal sepsis. Exploratory laparotomy } \\
\text { Postoperative; drain peritonitis, removal of } \\
\text { adhesions; omentectomy; appendectomy. } \\
\text { Coronary disease history. } \\
\text { Invasive mechanical ventilation }\end{array}$ & 33 & 114 & 1,78850 & 32 & 93 & 1,53916 \\
\hline 7 & 79 & $\mathbf{M}$ & COPD & 35 & 121 & 1,7895802 & 33 & 116 & 1,81359 \\
\hline 8 & 82 & M & Pulmonary sepsis. Ventilatory failure secondary. & 175 & 601 & 1,78001 & 159 & 588 & 1,88679 \\
\hline 9 & 89 & M & $\begin{array}{l}\text { Renal failure unspecified. Other signs and } \\
\text { symptoms involving cognitive function and } \\
\text { awareness unspecified. Acute respiratory } \\
\text { Insufficiency }\end{array}$ & 16 & 54 & 1,7548875 & 16 & 36 & 1,16993 \\
\hline 10 & 86 & M & $\begin{array}{l}\text { Sepsis soft tissue. chronic pulmonary disease } \\
\text { exacerbation unspecified }\end{array}$ & 36 & 137 & 1,92811 & 34 & 118 & 1,79518 \\
\hline 11 & 83 & $\mathbf{M}$ & Gall bladder disease, unspecified & 213 & 798 & 1,9055 & 217 & 837 & 1,94753 \\
\hline 12 & 32 & $\mathbf{F}$ & $\begin{array}{l}\text { Diffuse alveolar hemorrhage, septic shock, } \\
\text { pneumonia in immune suppressed patient, } \\
\text { acute-pulmonary hipotemic pneunositosis, } \\
\text { double mitral valve lesion, minimal aortic } \\
\text { regurgitation, severe tricuspid failure, Systemic } \\
\text { erythematosus lupus, serosistis: pericardial } \\
\text { effusion without hemodynamic minimum } \\
\text { repercussion, severe pulmonary hypertension } \\
\text { type A. Background alveolar hemorrhage four } \\
\text { years ago. }\end{array}$ & 29 & 87 & 1,585 & 27 & 85 & 1,65450 \\
\hline 13 & 29 & M & $\begin{array}{l}\text { Congestive heart failure. Cardiogenic shock, } \\
\text { Terminal heart failure LVEF } 15 \% \text {. Dilated cardio } \\
\text { myopathy. Primary thrombophilia }\end{array}$ & 22 & 74 & 1,75 & 21 & 72 & 1,77761 \\
\hline 14 & 79 & $\mathbf{F}$ & $\begin{array}{l}\text { Atrial flutter fibrillation. Hypertension blood and } \\
\text { unclear history of heart arrhythmia, constant } \\
\text { oppressive chest pain, cardiac output, } \\
\text { respiratory failure requesting endotracheal } \\
\text { intubation performed cardiac enzymes reported } \\
\text { as positive curve starts vasoactive support to } \\
\text { maintain adequate perfusion pressures. UCl } \\
\text { torequest transfer to hemodynamic monitoring } \\
\text { and management. }\end{array}$ & 33 & 97 & 1,5555 & 32 & 100 & 1,64386 \\
\hline 15 & 83 & M & Gall bladder disease, unspecified & 211 & 800 & 1,92276 & 194 & 711 & 1,87379 \\
\hline 16 & 62 & $\mathbf{F}$ & $\begin{array}{l}\text { Septic shock of abdominal origin, with suspected } \\
\text { intestinal fistula }\end{array}$ & 48 & 171 & 1,83289 & 48 & 175 & 1,86625 \\
\hline 17 & 82 & $\mathbf{M}$ & Pulmonary sepsis. Ventilatory failure secondary. & 390 & 1456 & 1,90046 & 399 & 1439 & 1,85061 \\
\hline 18 & 70 & M & $\begin{array}{l}\text { Cancer of the bile duct extrahapatica. Severe } \\
\text { sepsis source to establish Severe ARDS }\end{array}$ & 33 & 97 & 1,5555 & 32 & 100 & 1,64386 \\
\hline 19 & 79 & M & $\begin{array}{l}\text { Frontopariental hemorrhagic stroke left primary } \\
\text { Vs secondary malformation }\end{array}$ & 16 & 54 & 1,5555 & 16 & 36 & 1,16993 \\
\hline 20 & 67 & M & $\begin{array}{l}\text { Epilepsy. Unspecified pneumonia. Unspecified } \\
\text { heart failure, chronic obstructive pulmonary } \\
\text { disease unspecified }\end{array}$ & 59 & 180 & 1,60921 & 58 & 189 & 1,70426 \\
\hline
\end{tabular}

in a universal way, being applicable to each particular case. The time, in hours, required to the predictions, could be adjusted with further studies.

In a previous study, from spaces occupied by the 


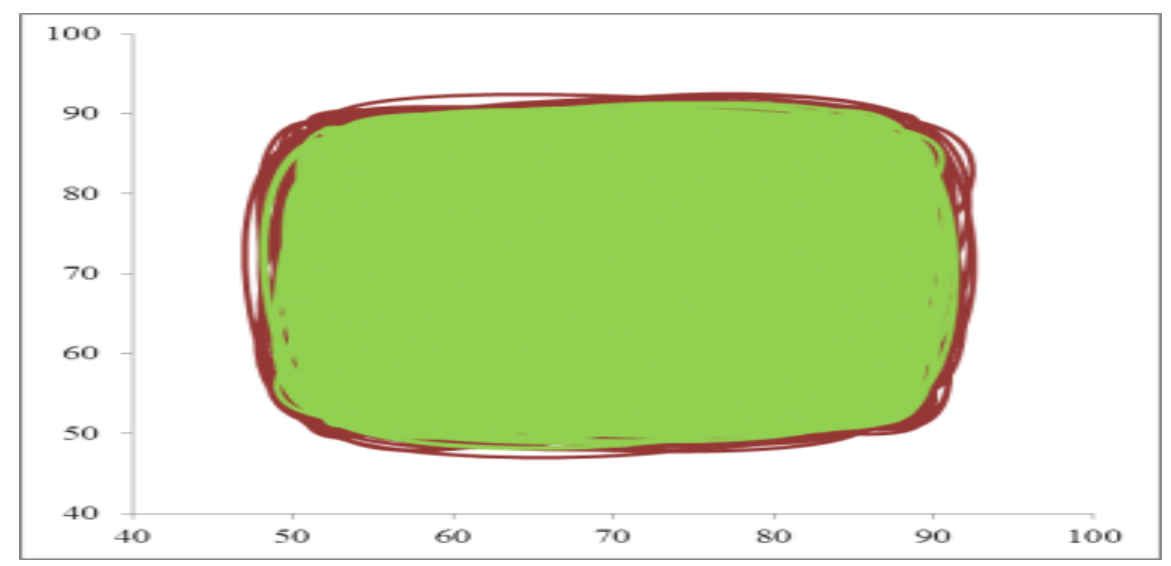

Figure 5. Pathological cardiac dynamics attractor corresponding to patient No. 6 (Table 3). The similarity of the space occupied between the two attractors can be observed, one generated with data for 21 hours (red) and the other for 15 hours (green) obtaining measures of 114 for 21 hours and 93 for 16 hours, in Kp grid.

attractor of cardiac dynamics in less than 21 hours, it was possible to differentiate between normal and acute illness (Rodríguez et al., 2008, Rodríguez et al., 2011b, Rodríguez et al., 2015e), subsequently reducing the evaluation time (Rodríguez et al., 2015d). Here, a reduction to 15 hours is achieved, being useful to study the evolution in less time. Other diagnostic physicalmathematical methodologies (Rodríguez 2011, Rodríguez et al., 2013a; Rodríguez, 2010b; Rodriguez 2012a; Rodríguez et al., 2013e; Rodríguez, 2014b) could also be applied to the ICU. Different mathematical methods for the study of heart rate variability have been developed (Perkiömäki et al., 2002; Lin et al., 2001; Voss et al., 2009; Perkiömäki et al., 2005) being its clinical applicability still discussed. In this study, the HR along with the other three variables analyzed in the context of set theory allow to establish an objective assessment of the dynamics of the system, showing a simultaneous selforganization of clinical application, where the predictions were corroborated by the blind studies developed. These would be useful for evaluating the effect of pharmacological or surgical interventions, regardless of population variables.

In cardiac dynamics, from entropy proportions, postoperative predictions were developed, taking two specific cases, including one of coronary ablation postoperative for which, the evolution of patient (Rodríguez, 2010b) was mathematically predicted from declining values of thousands, values that reflect how far the dynamics is from normal obtaining following values; Day 1: 0.88 , Day 2: 0,60 and Day 3: 0.41 , showing recovery, which was confirmed clinically. The other case is a patient who underwent cardiac catheterization and colocation of a stent in the right coronary artery, values of thousands were on Day 1: 0.95, Day 2: 0.94 and Day 3: 2.71 (Rodríguez et al., In press), on day 3 a worsening of cardiac dynamic system evolution occurs, which was confirmed clinically because the patient had an acute myocardial infarction. On the other hand, predictions of the number of T CD4+ cells have been developed from set theory and probability theory (Rodríguez et al., 2012; Rodríguez et al., 2011a; Rodríguez et al., 2013b; Rodríguez et al., 2013d; Rodríguez et al., 2014a) applied to the information of $\mathrm{CBC}$, which have been confirmed with 800 (Rodríguez et al., 2013d) and 500 (Rodríguezet al., 2013b) cases; this methodology has been improved and applied to 150 cases (Rodríguezet al., 2014a), and the prediction was extended for patients with CD4 lymphocyte population below 200CD4/ul; thus, there is an alternative for monitoring treatment in patients with HIV, more affordable and accessible especially in those regions of the world with limited resources. In this paper, at joining the two theories from induction, it is described the phenomenon quantitatively and qualitatively, establishing mortality predictions.

The determinism based on causality was reevaluated from the appearance of physical theories like statistical mechanics (Matvéev, 1987; Tolman, 1979), quantum mechanics (Feynman et al., 1964a) and chaos theory (Fernández, 1990), opening doors to causeless conception of phenomena. From this perspective, Prigogine affirms that for understanding of the phenomena we only have temporal windows, quantifications achieved by the developed methodology are causeless temporal windows, from simultaneous mathematical relations where is possible to find all dynamics of evolution to mortality, taking medicine to generalizations. Temporal windows have shown to be useful in diagnosis of uterine cervix cells (Prieto et al., 2014), displaying the possible trajectories (Rodríguez et al., 2015b) between normality to cancer, evaluating the proportion of nucleus and cytoplasm occupation space. From this perspective, it is possible that patients 
appear between both sets, meaning we can find patients progressing to an alive outcome or mortality, which makes the evolution of temporal windows useful in the evaluation of the critical patient in these cases and applicable in any other specific patient.

The developed methodology follows the generalist perspective of theoretical physics; during millenniums, empirical tables about movement of celestial bodies were developed, but Newton achieved a complete understanding about mechanics in a single equation (Feynman et al., 1964b) in which all empiric tables are deduced, and phenomena is predicted doing experiments to confirm what it was already known, unlike empirism, which makes experiments to know how nature works. With these sets, all empiric tables can be built for these variables in the ICU avoiding classifications whether a patient is classified with sepsis or postsurgical o coronary, etc., and as Kant affirms, about the method in physics (Kant 1905): "They comprehended that reason has insight into that only, which she herself produces on her own plan, and that she must move forward with the principles of her judgments, according to fixed law, and compel nature to answer her question". In this direction, clinical and experimental information has been taken to the context of predictive physical and mathematical laws and principals, elevating critical medicine to theoretical physics level.

In addition to the aforementioned, (Rodríguez et al., 2002; Rodríguez et al., 2010b; Prieto et al., 2014; Rodríguez et al., 2015b; Rodríguez et al., 2008; Rodríguez et al., 2011b; Rodríguez et al., 2015e; Rodríguez et al., 2015d; Rodríguez, 2011; Rodríguez et al., 2013a; Rodríguez, 2010b; Rodriguez, 2012a; Rodríguez et al., 2013e; Rodríguez, 2014b; Rodríguez, 2015; Rodríguez et al., 2012; Rodríguez et al., 2011a; Rodríguez et al., 2013b; Rodríguez et al., 2013d; Rodríguez et al., 2014a), other methodologies based on physics and mathematics have been developed in different branches of medicine; from dynamic systems theory and application of Boltzmann-Gibbs entropy law, differentiation between normality and disease was achieved in fetal monitoring (Rodríguez 2012b); in neonatal cardiac dynamic, quantification of progression to sepsis based on occupation spaces in a range of time between 6 and 3 hours previous to the septic event was developed (Rodríguez et al., 2014c), predictions of binding of peptides of Plasmodium falciparum to HLA-II in molecular biology was achieved (Rodríguez et al., 2010a), as well as prediction on epidemics dynamic (Rodríguez, 2010a), Rodríguez and Prieto, 2010; Rodríguez, 2009; Rodríguez, 2009; Rodríguez, 2013c, Rodríguez, 2011c; Rodríguez et al.,2015a).

\section{ACKNOWLEDGEMENT}

I want to thank to Signed Prieto Bohórquez by her surrender to mathematical harmony of the universe, and by to follow the creative path and systematic thinking, in the life. This work is result of the protocol C025-2014, financed by the research fund of the Hospital Militar Central. We extend our thanks to Dr. Luz Mabel Avila, Chief Scientific Research Unit, to Medical Colonel Dr. Luis Castro, Assistant Director of Teaching and Scientific Research and to accountant Jaime Sánchez for his support. I would like to thank the Insight Group for their support of my scientific trajectory. I also thank Dr. Henry Oliveros, director of post-surgical ICU of the Hospital Militar Central, where this research was developed.

We also thank to Research Center of Clínica del Country, especially to Dr. Tito Tulio Roa, Director of Medical Education; to Dr. Jorge Ospina, Medical Director, to Dr. Natalia Malaver, to Dr. Alfonso Correa, Director of Research Center; to Dr. Lizbeth Ortiz, epidemiologist and to Silvia Ortiz, Chief Nurse of the Research Center, for their support to our work. Also to nurse Sandra Rodriguez, and bacteriologist: Camilo Benítez and Juan Alexander Rojas.

In the same way special thanks, to Brigadier General Hugo Rodriguez Durán, rector of the Universidad Militar Nueva Granada, to Dr. Martha Bahamon, Academic Vicepresident, to Medicine, Basic Sciences, Engineering and Education Faculties, for their support to our investigations.

\section{DEDICATORY}

I dedicate this article to my mother, to my sons, to my nephews and my students. The formula to produce maximum results is to ignore obstacles and negative influences that resist the action takes place. Man must surrender into action and continue it, until the desired results are produced. Maharishi Mahesh Yogi.

\section{REFERENCES}

Braun C, Kowallik P, Freking A, Hadeler D, Kniffki K, Meesmann M (1998). Demonstration of nonlinear components in heart rate variability of healthy persons Am. J. Physiol.; 275, H1577-H1584.

Cismondi F, Celi LA, Fialho AS, Vieira SM, Reti SR, Sousa JM, Finkelstein SN (2013). Reducing unnecessary lab testing in the ICU with artificial intelligence. Int. J. Med. Inform. 82(5): 345-358

Costa M, Goldberger AL, Peng CK (2002). Multiscale Entropy Analysis of Complex Physiologic Time Series. PhysRevLett.;89 (6): 0681021 $-4$.

Devaney R (1992). A first course in chaotic dynamical systems theory and experiments. Reading Mass.: Addison- Wesley.

Eckmann JP, Ruelle D (1985). Ergodic theory of chaos and strange attractors, Rew. Mod. Physics. 7 617-656.

Fernández A (1990). Movimientocaótico. En: Orden y Caos. Scientific American. PrensaCientífica S.A.;. p. 66, 77.

Feynman RP, Leighton RB, Sands M (1964a). Comportamientocuántico. En: Feynman RP, Leighton RB, Sands M. Física. Vol. 1. Wilmington: Addison-Wesley Iberoamericana, S. A.; p. 37-1, 37-15.

Feynman RP, Leighton RB, Sands M (1964b). Leyes de Newton de 
la dinámica. En: Feynman RP, Leighton RB, Sands M. Física. Vol. 1. Wilmington: Addison-Wesley Iberoamericana, S. A.; p. 9-1, 9-10.

Figueredo MOL, González DS (2010). Morbimortalidad en la Unidad de CuidadosIntensivos. Rev ElectrónicaPortalesMédicos.;1-22

Goldberger A, Amaral L, Hausdorff JM, Ivanov P, PengCh, Stanley HE (2002). Fractal dynamics in physiology: alterations with disease and aging. PNAS; 99: 2466 - 2472.

Goldberger A, Rigney DR, West B (1990). Chaos and Fractals in human physiology. Sci Am. Feb;262(2):42-9.

Goldberger A, West BJ (1987). Fractals in physiology and medicine. Yale J Biology; 60: 421-35.

Gómez D, Fernández G, Gutiérrez Á, Daza L, Fernández C, Manrique N (2000). Cálculo de los contenidos arterial y venoso de oxígeno, de la diferenciaarteriovenosa de oxígeno, tasa de extraccióntisular de oxígeno y shunt intrapulmonar con unasnuevasfórmulas, basadas en la saturación de oxígeno. Revistafacultad de medicina.; 48(2): $67-76$

Gough N (1992). Fractals, chaos, and fetal heart rate. Lancet; 339: 1823 .

Grassberger P, Procaccia I (1983). Measuring the strangeness of strange attractors, Physica 9D 189-208.

Higgins JP (2002). "Nonlinear systems in medicine". Yale. J. Biol. Med.; 75: $247-60$.

Hosseini M, Ramazani J (2015) Comparison of acute physiology and chronic health evaluation II and Glasgow Coma Score in predicting the outcomes of Post Anesthesia Care Unit's patients. Saudi J Anaesth. 9(2):136-41.

Hsieh, Y. Su M, Wang C Wang P (2014). Prediction of survival of ICU patients using computational intelligence. Computers in Biology and Medicine. Vol 47. April.. 13-19.

Huikuri HV, Mäkikallio TH, Peng Ch, Goldberger AL, Hintze U, Moller M (2000). Fractal correlation properties of R-R interval dynamics and mortality in patients with depressed left ventricular function after an acute myocardial infartion. Circulation; 101: 47-53.

Kant I (1905). Critique of Pure Reason. Preface to 2nd edition, Tr. F. Max Müller.

Kinsner W (2007). A unified approach to fractal dimensions, JCINI 1 2646.

Knaus WA, Draper EA, Wagner DP, Zimmerman JE (1985). APACHE II: a severity of disease classification system. Crit Care Med. Oct;13(10):818-29.

Lefebvre F, Benali $H$ (1995). A fractal approach to the segmentation of microcalcifications in digital mammograms. Med. Phys. 22:381-390.

Lin LY, Lin JL, Du CC, Lai LP, Tseng YZ, Huang SK. (2001). Reversal of deteriorated fractal behavior of heart rate variability by betablocker therapy in patients with advanced congestive heart failure. J. Cardiovasc. Electrophysiol. 12, 26-32 10.1046/j.15408167.2001.00026.x

Le Gall JR, Lemeshow S, Saulnier F (1993). A new Simplified Acute Physiology Score (SAPS II) based on a European/North American multicenter study. JAMA. 270 (24):2957-2963

Luis JM, Montero PFJ (2006). Medicina de urgencias y emergencias: guíadiagnóstica y protocolos de actuación. $3^{\mathrm{a}} \mathrm{Ed}$, Madrid: Elsevier;

Mandelbrot B (1972). Scaling and power laws without geometry. In: The Fractal Geometry of Nature. Freeman Ed. San Francisco, P. 344-8.

Mandelbrot B (1972). The Fractal Geometry of Nature. Freeman Ed. San Francisco, , 341-348.

Matvéev A (1987). Física molecular. Primeraedición, Moscú; MIR. [ Links ]

Peitgen $H$ (1992). Length area and dimension. Measuring complexity and scalling properties. En: Chaos and Fractals: New Frontiers of Science. New York: Springer-Verlag;. p. 183-228.

Perkiömäki J, Mäkikallio TH, Huikuri HV (2005). Fractal and Complexity Measures of Heart Rate Variability. Clin. Exp. Hypertens. 2 \& 3,149-158.

Perkiömäki J, Zareba W, Badilini F, Moss AJ (2002). Influence of atropine on fractal and complexity measures of heart rate variability. Ann. Noninv. Electrocardiol. 7, 326-331

Pohlman S, Powell K, Obuchowski NA (1992). Quantitative classification of breast tumors in digitized mammograms. Med.Phys 23:1337-1345
Prieto S, Rodríguez J, Correa C, Soracipa Y (2014). Diagnosis of cervical cells based on fractal and Euclidian geometrical measurements: Intrinsic Geometric Cellular Organization. BMC Medical Physics, 14(2):1-9.

Rodríguez J (2009). Dinámicaprobabilista temporal de la epidemia de malaria en Colombia. Rev Med;17 (2): 214-21.

Rodríguez J (2010a). A method for forecasting the seasonal dynamic of malaria in the municipalities of Colombia. Rev Panam Salud Pública.; 27(3):211-218.

Rodríguez J (2010b). Proportional entropy of the cardiac dynamic systems Physical and mathematical predictions of the cardiac dynamic for clinical application. Rev ColombCardiol.; 17:115-129.

Rodríguez J (2011). Mathematical law of chaotic cardiac dynamic: Predictions of clinic application. J Med. Med. Sci.; 2(8):1050-1059.

Rodriguez J (2012a) .Proportional Entropy applied to the Clinic Prediction of Cardiac Dynamics. Innovations in Cardiovascular Interventions. ICI meeting, Tel Aviv-Israel.

Rodríguez J (2012b). New physical and mathematical diagnosis of fetal monitoring: clinical application prediction. MomentoRevista de Física.; 44: 49-65.

Rodríguez J (2005). Fractal behavior of T specify repertory against Poa p9 alergeno. Rev Fac Med UnivNacColomb 2005; 53:72-8.

Rodríguez J (2015). Mathematics physical assessment of cardiac dynamics based on theory of probability and proportions of entropy in the intensive care unit for patients with arrhythmia. Medical Physics. Birmingham, UK.

Rodríguez J, Prieto S, Melo M, Domínguez D, Correa C, Soracipa $\mathrm{Y}$, Mejía M, Valero L (2014a). Salamanca A. Prediction of the number of CD4 T lymphocytes in peripheral blood from sets and probability theories in patients with HIVIAIDS. Inmunologia.;33:113-20

Rodríguez J, Bernal P, Prieto S, Correa C (2010a). Theory of malaria peptides with high-affinity binding to red blood cells. Theoretical predictions of new binding peptides and predictive mutations of critical amino acids. Inmunología; 29(1):7-19.

Rodríguez J, Correa C (2009). Predicción temporal de la epidemia de dengue en Colombia: DinámicaProbabilista de la Epidemia. Rev. saludpública.; 11(3): 443-53.

Rodríguez J, Correa C, Melo M, Domínguez, D, Prieto S, Cardona DM (2013a). Chaotic cardiac law: Developing predictions of clinical application. J. Med. Med. Sci. 4(2): 79-84.

Rodríguez J, Mariño M, Avilán N, Echeverri D (2002). Medidas fractales de arterias coronarias en un modelo experimental de reestenosis. Armonía matemática intrínseca de la estructura arterial. Rev. Colomb. Cardiol. 10:65-72.

Rodríguez J, Prieto S (2010). Dynamic of the malaria epidemic. Epidemicpathpredictions. Rev Fac Med;18 (2): 12-20.

Rodríguez J, Prieto S, Avilán N, Correa C, Bernal P, Ortiz L (2008). Ayala J.New physics and mathematics methodology in Holter evaluation. Rev. Colomb. Cardiol. 15: 50-54.

Rodríguez J, Prieto S, Bernal P, Izasa D, Salazar G, Correa C, et al. Entropía proporcional aplicada a la evolución de la dinámicacardiaca. Predicciones de aplicaciónclínica. Comunidad de PensamientoComplejo (CPC), editor. Argentina: La emergencia de los enfoques de la complejidad en América Latina: desafíos, contribuciones y compromises para abordar los problemas complejos del siglo XX; In Press.

Rodríguez J, Prieto S, Bernal P, Pérez C, Correa C, Álvarez L (2012). Predicción de la concentración de linfocitos T CD4 en sangre periférica con base en la teoría de la probabilidad. Aplicación clínica en poblaciones de leucocitos, linfocitos y CD4 de pacientes con VIH. Infectio.; 16(1): 15-22.

Rodríguez J, Prieto S, Bernal P, Pérez C, Correa C, Vitery S (2011a). Teoría de conjuntos aplicada a poblaciones de leucocitos, linfocitos y CD4 de pacientes con VIH. Predicción de linfocitos T CD4, de aplicación clínica. RevFacMed; 19(2):148-156.

Rodríguez J, Prieto S, Bernal P, Soracipa Y, Salazar G, Isaza D, Cruz LE, Correa C (2011b). Nueva metodología de ayuda diagnóstica de la dinámica geométrica cardiaca. Dinámica cardiaca caótica del Holter. Rev. Acad. Colomb. Cienc. 35 (134): - .. ISSN 0370-3908.

Rodríguez J, Prieto S, Corre C, Forero M, Pérez C, Soracipa Y (2013b) Set theory applied to white cell and lymphocyte counts: prediction of 
CD4T lymphocytes in patients with human immunodeficiency virus/AIDS. Inmunología.; 32(2): 50-56.

Rodríguez J, Prieto S, Correa C (2015a). Predicciones de la dinámica del número de infectados de malaria en departamentos de Colombia a partir de la probabilidadrecurrente. III CONGRESO NACIONAL DE SALUD PÚBLICA "InvestigaciónCientífica e Innovación al Servicio

de la SaludPública". InstitutoNacional de Salud. Bogotá, D.C, Octubre 5 al 8 de

Rodríguez J, Prieto S, Correa C, Arnold Y, Alvarez Y, Bernal P (2013c). Dinámica de la epidemia del dengue en Colombia: Predicciones de la trayectoria de la epidemia. Rev. Fac. Med.; 21(1): 38-45.

Rodríguez J, Prieto S, Correa C, Bernal P, Puerta G, Vitery S,

Soracipa Y, Muñoz D (2010b). Theoretical generalization of normal and sick coronary arteries with fractal dimensions and the arterial intrinsic mathematical harmony. BMC Medical Physics; 10:1.

Rodríguez J, Prieto S, Correa C, Dominguez D, Cardona DM, Melo M (2015b). Geometrical nuclear diagnosis and total paths of cervical cell evolution from normality to cancer. Journal of CancerResearch and Therapeutics; (11 - Issue 1): 98-104.

Rodríguez J, Prieto S, Correa C, Mendoza F, Weiz G, Soracipa Y, Velásquez N, Pardo J, Martínez M, Barrios F (2015c). Physical mathematical evaluation of the cardiac dynamic applying the Zipf Mandelbrot law. Journal of Modern Physics, 6, 1881-1888. http://dx.doi.org/10.4236/jmp.2015.613193

Rodríguez J, Prieto S, Correa C, Mora J, Bravo J, Soracipa Y (2013d). Predictions of CD4 lymphocytes' count in HIV patients from complete blood count. BMC Medical Physics. BMC Medical Physics.; 13:3.

Rodríguez J, Prieto S, Correa C, Oliveros H, Soracipa Y, Amaya J (2015d). Sistemas dinámicos aplicados a la disminución del tiempo de diagnóstico de la dinámica cardiaca de 24 a 16 horas en holter y registros electrocardiográficos continuos. $X$ Congreso de Medicina Crítica y Cuidado Intensivo. Cartagena, Colombia.

Rodríguez J, Prieto S, Correa C, Soracipa Y, Aguirre G, Méndez L (2014b). Proportional entropy applied to the clinical diagnostic of cardiac dynamic: blind study with 600 holter. The 61st Annual Conference of the Israel Heart Society in association with The Israel Society of Cardiothoracic Surgery..

Rodríguez J, Prieto S, Correa C, Soracipa $Y$, Méndez L, Bernal H, Hoyos N, Valero L, Velasco A, Bermúdez E (2015e). Nueva metodología de evaluación del Holter basada en los sistemas dinámicos y la geometría fractal: confirmación de su aplicabilidad a nivel clínico. RevUnivInd Santander Salud.; 47(3). In press.

Rodríguez J, Prieto S, Domínguez D, Melo M, Mendoza F, Correa C (2013e). Mathematical-physical prediction of cardiac dynamics using the proportional entropy of dynamic systems. J. Med. Med. Sci.; 4(8): 370-381.
Rodríguez J, Prieto S, Flórez M, Alarcón C, López R, Aguirre G, Morales L, Lima L, Méndez L (2014c). Physical-mathematical diagnosis of cardiac dynamic on neonatal sepsis: predictions of clinical application. J.Med.Med. Sci.; 5(5): 102-108.

Rodríguez J, Vitery S, Puerta G, Muñoz D, Rojas I, Pinilla L (2011c). Dinámicaprobabilista temporal de la epidemia de dengue en Colombia. Rev CubanaHigEpidemiol.; 49(1):74-83

Rowan KM, Kerr JH, Major E, McPherson K, Short A, Vessey MP (1993). Intensive Care Society's APACHE-II study in Birtain and Ireland-II: outcome comparisons of intensive care units after adjustment for case mix by the American APACHE-II method. BMJ; 307:977-81.

Tolman R (1979). Principles of statistical mechanics. Primeraedición. New York: Dover Publications;

Voss A, Schulz S, Schroeder R, Baumert M, Caminal P (2009). Methods derived from nonlinear dynamics for analysing heart rate variability. Phil. Trans. R. Soc. 367A, 277-296.

West JW (1990). Fractal physiology and chaos in medicine. Singapore: world scientific

Wu GQ, Arzeno NM, Shen LL, Tang DK, Zheng DA, Zhao NQ, Eckberg DL, Poon CS (2009). Chaotic Signatures of Heart Rate Variability and Its Power Spectrum in Health, Aging and Heart Failure. PLoS ONE. (2) 4 e4323.

Zipf, G (1949). Human behaviour and the principle of least effort: An introduction to human ecology. Cambridge, MA: Addison-Wesley. 